\title{
STRATEGI BRAND ACTIVATION BANDENG MENTARI UMKM UD. SARANA MULTI NIAGA KABUPATEN GRESIK
}

\author{
Ellyda Retpitasari ${ }^{1}$, Muchlis ${ }^{2}$
}

\author{
${ }^{1-2}$ Universitas Islam Negeri Sunan Ampel Surabaya
}

1ellyda@gmail.com, ${ }^{2}$ muchlis79@ uinsby.ac.id

\begin{tabular}{l}
\hline \hline Article Info \\
\hline \\
Article history: \\
Received 14 February 2018 \\
Accepted 16 March 2018 \\
Published 10 April 2018 \\
\hline
\end{tabular}

\section{Keyword:}

Strategi brand activation, brand awareness, UMKM

\section{Abstract}

Dalam penelitian ini, peneliti membahas tentang strategi brand activation bandeng mentari usaha mikro, kecil, dan menengah (UMKM) UD. Sarana Multi Niaga Kabupaten Gresik. Tujuan dalam penelitian ini adalah untuk mengetahui tentang strategi brand activation yang digunakan UMKM UD. Sarana Multi Niaga Kabupaten Gresik dalam rangka untuk mewujudkan awareness konsumen, dan bentuk brand activation yang digunakan UMKM UD. Sarana Multi Niaga dalam rangka untuk mewujudkan awareness. Metode penelitian ini menggunakan metode kualitatif deskriptif.

Hasil penelitian ditemukan bahwa, UMKM UD. Sarana Multi Niaga menjalankan strategi melalui segmentation, targeting dan positioning. Kemudian bentuk brand activation menggunakan sponshorship, product trial, dan direct selling. Strategi dan bentuk brand activation itu digunakan untuk mewujudkan kesadaran merek (brand awareness) dari konsumen, haltersebut diwujudkan dengan brand Bandeng Mentari dikenal sebagai kearifan lokal dari kabupaten Gresik

\section{Editorial Office:}

Program Studi Ilmu Komunikasi, Fakultas Dakwah dan Komunikasi, UIN Sunan Ampel Surabaya. Jl. Ahmad Yani 117 Surabaya, Jawa Timur, Indonesia.

Email: jurnalilkom@uinsby.ac.id 


\section{Pendahuluan}

UMKM akronim dari Usaha Mikro, Kecil dan Menengah, memiliki beragam peranan penting dalam pertumbuhan ekonomi, pada tahun 1997 Indonesia mengalami krisis moneter, dalam hal tersebut UMKM menjadi penyelamat dalam proses pemulihan ekonomi nasional. Selain itu, UMKM juga berperan penting sebagai alternatif penyediaan lapangan kerja baru, UMKM berperan baik dalam mendorong laju pertumbuhan ekonomi dan sebagai pengentasan kemiskinan maupun penyerapan tenaga kerja.

Kegiatan UMKM meliputi berbagai kegiatan ekonomi, namun sebagian besar berbentuk usaha kecil yang bergerak disektor pertanian. data Biro Pusat Statistik (BPS) 1996 menunjukkan, jumlah UMKM sebanyak 38,9 juta dengan rincian: sektor pertanian berjumlah 22,5 juta $(57,9 \%)$; sektor industri pengolahan 2,7 juta $(6,9 \%)$; sektor perdagangan, rumah makan dan hotel sebanyak 9,5 juta (24\%); dan sisanya bergerak di bidang lain. Dari segi nilai ekspor nasional (BPS, 1998), Indonesia jauh tertinggal bila dibandingkan ekspor usaha kecil negara-negara lain, seperti Taiwan (65\%), China (50\%), Vietnam (20\%), Hongkong (17\%), dan Singapura (17\%). Oleh karena itu, perlu dibuat kebijakan yang tepat untuk mendukung UMKM seperti antara lain: perijinan, teknologi, struktur, manajemen, pelatihan dan pembiayaan,sedangkan data biro pusat statistik tahun 2010 menyatakan bahwa UMKM dari sektor mikro saja sudah mencapai 52 juta unit usaha atau

\footnotetext{
${ }^{1}$ BPS.go.id diakses pada tanggal 15 November 2017
}

sekitar $99 \%$ dari total UMKM, dan menyumbang rata-rata $33,8 \%$ PDB (product domestic bruto) dari total keseluruhan PDB nasional. ${ }^{1}$

Hasil analisis makro ekonomi UMKM memiliki peran strategis dalam pendapatan nasional dan pengurangan pengangguran sesuai dengan UU No. 20 th 2008 bab III pasal V yang berbunyi :

"Meningkatkan peran Usaha Mikro, Kecil, dan Menengah dalam pembangunan daerah, penciptaan lapangan kerja, pemerataan pendapatan, pertumbuhan ekonomi, dan pengentasan rakyat dari kemiskinan".

Dalam ekonomi makro salah satu yang menjadi pokok permasalahan adalah pengangguran dan membahas tentang pendapatan nasional atau pertumbuhan ekonomi. Dalam hal ini UMKM memainkan perannya, diantaranya dalam mengurangi pengangguran UMKM telah berperan aktif menyerap tenaga kerja, yang secara tidak langsung mengurangi tingkat pengangguran di Indonesia. Dan juga dalam hal pendapatan nasional UMKM juga mempunyai kontribusi diantaranya melalui pajak yang harus di keluarkan. rangan pengangguran dan berperan dalam pendapatan nasional.

UMKM memiliki beragam peranan penting dalam pertumbuhan ekonomi, pada tahun 1997 Indonesia mengalami krisis moneter, pada saat itu, UMKM mampu memberikan kontribusi dalam mendorong pertumbuhan ekonomi dan dapat dipandang sebagai media penyelamat dalam proses pemulihan ekonomi nasional. 
Data BPS menunjukkan bahwa pada maret

2013, jumlah penduduk miskin (penduduk dengan pengeluaran per kapita bulan di bawah garis miskin) di Indonesia mencapai 28,07 juta orang (11,37 persen). Peranan komoditi makanan terhadap garis kemiskinan jauh lebih besar dibandingkan bukan makanan (sumber: Badan Pusat Statistika, 2013).

Banyaknya jumlah UKM di Indonesia mencapai 56,2 juta unit ${ }^{2}$ membuat mereka harus bersaing untuk mendapatkan awareness dari target pasarnya agar konsumen mengenal dan mempergunakan produk atau jasa yang ditawarkan. Sehingga untuk mampu mempengaruhi kelangsungan hidup suatu perusahaan dibutuhkan usaha untuk melakukan promosi dan komunikasi. Bahkan Usaha Mikro, Kecil dan Menengah (UMKM) membutuhkan sebuah strategi dalam memperkuat mereknya. Apalagi UMKM di Indonesia saat ini, ikut dalam membantu percepatan ekonomi dan menjadi tembok besar dalam menghadapi era pasar bebas saat ini.

Salah satu kesuksesan UMKM dapat diperhatikan bagaimana pelaku UMKM dalam mempromosikan brand-nya. Tanpa brand yang dikenal oleh konsumen, maka suatu produk/jasa akan sulit terjual dan mempengaruhi berjalannya suatu usaha. Sehingga, dengan penerapan pemasaran yang baik maka dapat memberikan efek terhadap suatu merek, terutama merek dari suatu produk UMKM seperti halnya dengan UMKM yang memproduksi makanan dan minuman, disini peneliti tertarik pada UMKM produk Olahan
Bandeng. Dimana UMKM yang peneliti pilih disini merupakan UMKM yang memiliki brand unik dan menarik. UMKM UD. Sarana Multi Niaga memiliki Brand Bandeng.

Perkembangan olahan bandeng sebagai komoditi dagang di usaha makanan dan kuliner berkembang pesat di Gresik. Perkembangan ini terjadi seiring dengan meningkatnya jumlah wisatawan yang berlibur ke Gresik, terutama pada destinasi wisata rohani yakni Sunan Giri dan Sunan Maulana Malik Ibrahim, sehingga usaha olahan bandeng sebagai ussaha kuliner pun berkembang mengikuti permintaan konsumen yang juga semakin meningkat. Dampak positif dari perkembangan ini juga meningkatnya jumlah usaha mikro, kecil dan menengah (UMKM) yang memproduksi beragam olahan bandeng dimana keberadaan UMKM ini membantu menciptakan lapangan pekerjaan tersendiri

Berkembangnya olahan bandeng sebagai usaha kuliner dan pasar makanan yang menjanjikan, menyebabkan produsen olahan bandeng mengembangkan berbagai strategi untuk menarik minat konsumen dan menghadapi persaingan dengan produsen olahan bandeng lainnya, selain mengembangkan kemasan, inovasi produk, dan varian rasa, para produsen olahan bandeng juga memperhatikan sistem pemasaran untuk mempromosikan produknya.

Minimnya pemasaran yang dilakukan oleh para produsen bandeng, menyebabkan kebingungan oleh para konsumen, sehingga dalam mindset konsumen mengggeneralisasi pemikiran

\footnotetext{
${ }^{2}$ swa.co.id diakses pada tanggal 12 November 2017
} 
bahwa olahan bandeng yang dijual dimanapun memiliki rasa dan ciri khas yang sama, sehingga konsumen tidak menfokuskan pada pilihan satu merk olahan bandeng saja dan kebanyakan pembeli olahan bandeng yang dilakukan berdasarkan pada referensi pengemudi transportasi umum, pemandu wisata. Hal ini yang dilihat secara berbeda dengan Bandeng Mentari dari UMKM UD. Sarana Multi Niaga di Gresik. Bandeng Mentari tidak memfokuskan pada rasa dan varian produk dari bandeng itu sendiri, tetapi juga melakukan inovasi produk dan membangun merek Bandeng Mentari melalui brand activation untuk meningkatkan minat beli (awareness) konsumen terhadap produk olahan bandeng dari Bandeng Mentari.

Bandeng Mentari memiliki Potensi pasar bandeng tanpa duri ini meliputi potensi pasar domestik dan pasar luar negeri (ekspor). Data di lapangan menunjukkan Negara tujuan ekspor adalah Hongkong, Taiwan dan Malaysia. Untuk kebutuhan dalam negeri permintaan datang dari modern market (Hypermarket \& Supermarket) dan rumah makan/restoran. Berdasarkan data internal permintaan ikan bandeng tanpa duri mencapai angka 1 ton perminggu, jumlah tersebut diperkirakan akan terus meningkat seiring dengan perkembangan era modern, praktis, dan pola hidup sehat sehingga ikan menjadi salah satu pilihan utama dalam pemenuhan kebutuhan protein.

Bandeng Mentari mulai secara serius mengaktivasi mereknya dengan melihat pada persaingan di pasar produk olahan bandeng, mengetahui bahwa mereknya belum banyak dikenal oleh konsumen, maka Bandeng Mentari mulai secara serius mengaktivasi mereknya sebagai salah satu strategi mewujudkan awareness konsumen. Dalam hal ini UD. Sarana Multi Niaga menerapkan strategi pemasaran yang dilakukan memiliki cara yang berbeda dan spesifik dimasing-masing segmen pasar. Pada prinsipnya strategi yang kita terapkan adalah strategi harga, baik berupa diskon atau bonus dalam kelipatan pembelian tertentu. Selain itu, pada even tertentu kita juga berperan aktif mengikuti beberapa pameran dalam kota maupun luar kota, sebagi bentuk promosi dan pengenalan produk pada konsumen.

\section{Kajian Pustaka \\ Usaha Mikro, Kecil dan Menengah}

Secara umum, UKM atau yang biasa dikenal dengan usaha kecil menengah merupakan sebuah istilah yang mengacu pada suatu jenis usaha yang didirikan oleh pribadi dan memiliki kekayaan paling banyak Rp.200.000.000,00 (belum termasuk tanah dan bangunan). ${ }^{3}$ Dari pengertian tersebut, ada beberapa definisidefinisi UKM yang lain.

Usaha atau bisa disebut dengan kewirausahaan. Istilah kewirausahaan menurut Peggy A. Lambing dan Charles R. Kuel dalam bukunya Entrepeneurship adalah tindakan kreatif yang membangun suatu value dari sesuatu yang tidak ada. Entrepeneurship merupakan proses untuk menangkap dan mewujudkan suatu

\footnotetext{
3 Akifa P. Nayla, "Komplet Akutansi untuk UKM dan Warabala”, Jojakarta, 2014, hal 12
} 
peluang terlepas dari sumber daya yang ada, serta membutuhkan keberanian untuk mengambil risiko yang telah diperhitungkan. ${ }^{4}$

Menurut The American Heritage Dictionary, Wirausaha (Entrepeneur), didefinisikan dengan seseorang yang mengorganisasikan, mengoperasikan dan memperhitungkan risiko untuk sebuah usaha yang mendatangkan laba. Dalam pengertian ini, terdapat kata "mengorganisasikan", apakah yang diorganisasikan tersebut. Demikian juga terdapat kata "mengoperasikan" dan "memperhitungkan risiko". Seorang pelaku usaha dalam skala yang kecil sekalipun dalam menjalankan kegiatannya akan selalu menggunakan berbagai sumber daya. Sumber daya organisasi usaha meliputi, sumber daya manusia, finansial, peralatan fisik, informasi dan waktu. Dengan demikian seorang pelaku usaha telah melakukan "pengorganisasian" terhadap sumber daya yang dimilikinya dalam ruang dan dimensi yang terbatas dan berusaha "mengoperasikan" sebagai kegiatan usaha guna mencapai laba. Dalam mengorganisasikan dan mengoperasikan usahanya tersebut ia berhadapan dengan sejumlah risiko, utamanya risiko kegagalan. karena berbagai sumber daya yang dimiliki keterbatasan, jelas mengandung sejumlah risiko. Itulah hal yang dilakukan oleh seorang pelaku usaha yang memiliki jiwa kewirausahaan. ${ }^{5}$

\footnotetext{
${ }^{4}$ Tejo Nurseto, "Strategi Menumbuhkan Wirausaha Kecil Menengah yang Tangguh", dalam jurnal Ekonomi \& Pendidikan Vol. 1 No.1 Februari 2004, hal 3

5 Mulyadi Nitisusastro, Kewirausahaan \& Manajemen Usaha Kecil, (Bandung: Alfabeta,2010) hal 26-27
}

Profil dan karakteristik UKM yang ada di Indonesia dapat ditinjau dari beberapa aspek antara lain permodalan, skala usaha, macam usaha, tingkat pendidikan pengusaha maupun karyawan, profil UKM ini kita lihat dan bahas satu per satu. Dilihat dari macam usaha UKM jenis usaha UKM terbanyak bergerak pada bidang perdagangan besar dan eceran. Kegiatan ini banyak digeluti karena mudah melakukan, tidak membutuhkan modal yang besar, tidak memerlukan tempat khusus dan tidak memerlukan administrasi pengurusan usaha. UKM yang paling sedikit, bergerak pada bidang usaha listrik dan air bersih, ini disebabkan untuk usaha tersebut biasanya telah dilakukan oleh pemerintah daerah, karena bidang usaha tersebut memerlukan ketrampilan, permodalan dan peraturan khusus yang lebih besar serta rumit dibandingkan kegiatan perdagangan. ${ }^{6}$

\section{Metode Penelitian}

Dalam penelitian ini, peneliti menggunakan pendekatan Grounded Research, dimana menurut Nazir merupakan suatu metode penelitian yang mendasarkan diri kepada fakta dan perbandingan dengan tujuan untuk mengadakan generalisasi empiris, menetapkan konsep-konsep, membuktikan teori dan mengembangkan teori di mana pengumpulan data dan analisa data berjalan pada waktu yang bersama. Selain

6 Wahyuningsih, "Peran UKM dalam Perekonomian Indonesia”, dalam Jurnal Mediargo, Vol. 5, No.1, 2009 
itu juga untuk menspesifikasikan konsep serta memverifikasi terhadap teori yan sedang dikembangkan dan diperiksa dalam hubungannya dengan data yang ditemukan. Ciri-ciri dari Grounded Research yakni penggunaan data sebagai sumber teori, menonjolkan peranan data dalam penelitian, pengumpulan data dan analisa data dilakukan secara bersamaan, dan perumusan hipotesa berdasarkan kategori.

Adapun dalam penelitian ini peneliti menggunakan jenis penelitian kualitatif adalah metode untuk mengeksplorasi dan memahami. ${ }^{7} \quad$ Penelitian kualitatif merupakan pengumpulan data suatu latar alamiah, dengan menggunakan metode alamiah, dilakukan oleh peneliti yang tertarik dengan alamiah. ${ }^{12}$ Penelitian kualitatif bergantung dari pengamatan pada manusia, baik dalam kawasannya maupun peristilahannya ${ }^{8}$

\section{Tipe Bisnis UMKM dan Strategi Merek}

Dalam mengembangkan mereknya UMKMmenggunakan beberapa tipe bisnis dan strategi, diantaranya sebagai berikut; ${ }^{9}$

\section{Package Type}

UMKM menjual produk-produk yang cepat habis atau termasuk "fast moving consumer good" (FMCG, seperti: makanan, produk pembersih, permen, kue dan lain-lain). Perilaku konsumen dalam pembelian FMCG ini memiliki sifat selalu membandingkan

\footnotetext{
${ }^{7}$ John W. Creswell, Research Design Pendekatan Kualitatif, Kuantitatif, dan Mixed

(Yogyakarata: Pustaka Pelajar, Edisi Ketiga, 2009), hal 4

8 Lexy J. Moleong, Metodologi Penelitian Kualitatif (Bandung: PT. Rosda Karya, 2008), 3
}

product features satu yang lain sehingga peran merek menjadi penting.

Konsumen akan mengkaitkan sebuah nama dengan kategori tertentu, sehingga dapat memungkinkan pencapaian kedudukan top of mind. Bagaimana agar merek kita mudah diingat dan dikenal, strategi komunikasi menjadi penting, bentuknya bisa melalui iklan, promosi, penjualan, publikasi, tenaga penjualan dan pemasaran langsung. Wong dan Merriless mengajukan beberapa saran untuk mendukung aktivitas pemasaran pada UMKM yaitu;

1) Melakukan investasi merek untuk jangka panjang. 2) Mengembangkan merek yang unik. 3) Mengembangkan kesadaran kepada karyawan akan pentingnya merek perusahaan. 4) Mengkomunikasikan merek secara konsisten dan jelas melalui semua aktivitas pemasarannya.

\section{Component Type}

UMKM menjual barang-barang yang dibutuhkan industri. Dalam hal ini peran merek kurang begitu penting, dibandingkan barang- barang konsumen. Harga barang-barang modal relatif lebih mahal dibandingkan dengan harga barang konsumsi sehingga proses pembeliaannya biasanya panjang dan melibatkan banyak orang.

9 Rahab, , Penerapan Manajemen Merek Pada Ushaa Kecil dan Menengah (UKM) Fakultas Ekonomi Universitas Jendral Soedirman Purwokerto , Jurnal Bisnis dan Ekonomi (JBE), Maret 2009, Vol 16 No. 1, ISSN 1412-3126, hal 21 
3. Customer Interface Type

Usaha ini menghasilkan produk yang disertai pelayanan misalnya penjualan mobil disertai layanan purna jual. Dalam mengelola bisnis ini, pemasaran internal memegang peranan penting, yaitu perusahaan melatih dan memotivasi karyawannya agar melayani pelanggan dengan baik.

\section{Komunikasi Pemasaran Terpadu (Integrated Marketing communication)}

Komunikasi adalah sebuah proses sosial yang terjadi antara paling tidak sedikitnya dua orang, dimana seseorang mengirimkan sejumlah symbol tertentu kepada orang lain, seperti dalam definisi komunikasi yang dikemukakan oleh William Albight buku Siahaan, "Communication is the process of transmitting meaningfull symbols between individuals". ${ }^{10}$ Dari definisi diatas dapat diimplikasikan bahwa komunikasi terjadi bila kedua belah pihak saling mengolah dengan baik symbol-simbol yang disampaikan. Symbol-simbol tersebut disebut sebagai pesan, proses transmisi dilakukan melalui sejumlah wahana, dan terjadi sejumlah perubahan atau respon terhadap pesan yang disampaikan.

Menurut B. Helpris Estawara, Integrated marketing communication (IMC) atau Komunikasi Pemasaran Terpadu, adalah "Proses dan Konsep Manajemen pesan untuk menyelaraskan persepsi tentang nilai mereka melalui interaksi dengan semua significant

${ }^{10}$ Siahaan, S.M, Komunikasi, Pemahaman, dan Penerapan, (Jakarta: BPK GUnung Mulia, 1990), hal 3 audience perusahaan dalam jangka panjang dengan mengkoordinasikan secara sinergis semua elemen komunikasi guna mendukung efisiensi dan efektivitas kinerja bisnis dan pemasaran dalam mencapai tujuannya".

Definisi diatas pada dasarnya mengemukakan bahwa IMC adalah sebuah usaha penyelarasan berbagai resources yang di miliki oleh perusahaan dalam pelaksanaan kegiatan komunikasi pemasarannya. Definisi diatas juga mendudukan hakikat komunikasi yang bersifat strategis. Definisi tersebut diatas sesuai dengan apa yang di kemukakan oleh Kliatchko: IMC dibangun berdasarkan tiga gagasan utama, yaitu ${ }^{11}$ Pertama: IMC adalah konsep dan juga proses. Kedua : IMC adalah persoalan penyelerasan perusahaan dan Ketiga: IMC merupakan gejala komunikasi yang strategis dalam proses bisnis modern yang ditekankan pada persepsi tentang nilai merek dan interaksi.

IMC adalah persoalan penyelarasan perusahaan sehingga dalam mengelola perencanaan, pelaksanaan, dan pengevaluasian pesan-pesan komunikasi dibutuhkan pengetahuan dan skill tentang manajemen strategi. Memahami penyelarasan perusahaan dan proposisi akan mudah diawali dari pemahaman tentang bisnis. Menurut Skinner, bisnis dikatakan sebagai pertukaran barang dan jasa atau uang yang saling menguntungkan atau memberikan manfaat.

Sedangkan menurut arti dasarnya, bisnis memiliki makna sebagai the buying

\footnotetext{
${ }^{11}$ Kliatchko, J.Understanding Integrated marketing communications, Inkwell Publishing (2004)
} 
and selling of goods and service. Sedangkan perusahaan bisnis adalah suatu organisasi yang terlibat dalam pertukaran barang atau uang untuk menghasilkan keuntungan. Berdasarkan uraian diatas selain sebagai konsep bisnis juga dapat diartikan sebagai proses. Proses input, produksi, dan output atas barang dan jasa dengan memberikan manfaat yang dapat dipertukarkan untuk menghasilkan keuntungan. Perusahaan sendiri adalah organiasi yang bekerja untuk menghasilkan keuntungan atas barang dan jasa yang ditawarkan melalui proses bisnis.

\section{Hasil dan Pembahasan \\ Deskripsi Umum UD. Sarana Multi Niaga}

UD. Multi Sarana Niaga merupakan industri kecil mikro yang bergerak di bidang pengolahan hasil perikanan dan budidaya ikan bandeng. Industri ini muncul karena melihat potensi ikan bandeng di wilayah Gresik sangat luar biasa, artinya ketersedian bahan baku yang sangat banyak sehingga memungkinkan untuk dapat dikembangkan melalui penciptaan produk-produk olahan baru yang inovatif sehingga memiliki nilai tambah lebih dibandingkan dalam bentuk mentahnya. Selain itu, banyaknya duri yang terdapat pada ikan bandeng menyebabkan orang enggan untuk mengkonsumsinya, padahal disisi lain ikan bandeng memiliki kandungan gizi yang cukup tinggi dan rasa yang enak.

Oleh karena itu, UD. Sarana Multi Niaga mengembangkan teknologi untuk menghilangkan duri ikan bandeng dan mengolahnya menjadi berbagai macam makanan yang siap dikonsumsi oleh konsumen. Berbekal teknologi sederhana dan proses yang simpel serta didukung oleh tenaga profesional, Bapak Parmo selaku owner Bandeng Mentari mampu menciptakan beraneka ragam produk berbahan baku ikan bandeng produk. Proses pembuatan produk olahan ikan bandeng dilakukan dengan teliti dan higienis, berkesinambungan antara proses satu dengan proses lainnya, koreksi dan tindakan di setiap tahapannya, sehingga produk yang dihasilkan memiliki mutu prima.

Produk utama yang UD. Sarana Multi Niaga hasilkan adalah ikan bandeng segar dan olahan ikan bandeng seperti: Bandeng Tanpa Duri (Brand: Bandeng Mentari), Otak-otak Bandeng, Pepes Bandeng Tanpa Duri, Sapit Bandeng Tanpa Duri, Bandeng Presto, Abon Bandeng, dan aneka olahan lainnya berbasis daging lumatan seperti bakso ikan bandeng, nugget bandeng, kaki naga, kerupuk bandeng. Untuk produk kemasan sosis bandeng dan ikan bandeng kaleng masih dalam tahap perencanaan dan survei pasar.

UD. Multi Sarana Niaga berdiri pada tanggal 12 April 2011 dengan nomor pendirian 239/437.56/SIUP.K/IV/2011 diterbitkan oleh Kementerian Perindustrian dan Perdagangan, Surat Ijin Usaha Perikanan Nomor 523.3/2080/437.60/2012 dan Surat Penanganan Pengolahan Hasil Perikanan Nomor 523.3/2081/437.60/2012 diterbitkan oleh Kementerian Kelautan dan Perikanan Kabupaten Gresik. Industri ini berada di wilayah Gresik, tepatnya di Jl. Pendopo No.7A Sembayat, Kacamatan 
Manyar, Kabupaten Gresik yang merupakan salah satu wilayah penghasil ikan bandeng terbesar di Jawa Timur.

Industri ini adalah kelompok industri kecil pengolahan ikan bandeng dengan nama Bandeng Mentari yang memproduksi aneka olahan ikan bandeng, baik dalam bentuk ikan segar (boneless milkfish) maupun masakan (fastcook). Hal ini dilakukan untuk memenuhi kebutuhan pasar dan peningkatan konsumsi ikan masyarakat secara menyeluruh,

\section{Potensi dan Segmentasi Pasar Terpadu UD. Sarana Multi Niaga}

Potensi pasar bandeng tanpa duri ini meliputi potensi pasar domestik dan pasar luar negeri (ekspor). Data di lapangan menunjukkan Negara tujuan ekspor adalah Hongkong, Taiwan dan Malaysia. Untuk kebutuhan dalam negeri permintaan datang dari modern market (Hypermarket \& Supermarket) dan rumah makan/restoran. Berdasarkan data internal permintaan ikan bandeng tanpa duri mencapai angka 1 ton perminggu, jumlah tersebut diperkirakan akan terus meningkat seiring dengan perkembangan era modern, praktis, dan pola hidup sehat sehingga ikan menjadi salah satu pilihan utama dalam pemenuhan kebutuhan protein. Sedangkan strategi yang dilakukan adalah sebagai berikut;

\section{Mendekati Konsumen Secara Personal}

Proses brand activation dari UD. Sarana Multi Niaga terlihat ketika terlibat dalam sebuah event pameran, dimana dari pihak UD. Sarana Multi Niaga tidak mengutamakan penjualan sebagai hal utama, namun lebih mengutamakan presentasi dari produk, penawaran, dan mengambil hati pelanggan. Hal ini diwujudkan dengan cara pemberian tester, edukasi tentang olahan produk, pembagian kartu nama dan brosur.

Dalam unsur-unsur brand activation terdapat tiga poin yang harus diperhatikan diantaranya sebagai berikut: Relationship terkait dengan interaksi dan menghargai konsumen sekaligus memberikan pengalaman emosional yang dinginkannya. UD. Sarana Multi Niaga melibatkan konsumen dalam membangun sebuah merek. UD. Sarana Multi Niaga sendiri tidak membatasi segmentasi antara kelas atas maupun kelas bawah. Begitu pun dengan pendistribusian, UD. Sarana Multi Niaga juga membidik traditional market dan modern market. Traditional market seperti reseller, dan pasar tradisional. Sedangkan modern market seperti supermarket, dan rumah makan.

Sensorial experience, merupakan alat branding, memberikan konsumen pengalaman sensorik terkait merek dimana merek menjadi kunci utama dalam sebuah pengenalan produk, sehingga membangun preferensi merek dan loyalitas. Pemasaran dalam supermarket dan rumah makan yang bonafit sendiri, menjadi modal UD. Sarana Multi Niaga dalam memberikan pengalaman sensorik.

Imagination, sebuah pendekatan imajinatif dalam produk kemasan, toko retail, iklan dan situs web. Dalam hal ini, UD. Sarana Multi Niaga selaku melakukan evaluasi desain produk, 
sehingga dari tahun ke tahun mengalami re-design untuk mempertahankan merek dan mengenalkan merek dalam ranah yang lebih luas.

Adapun dalam implementasi brand activation terdapat tiga langkah penting yaitu;

a. Invitation (ajakan), Tahapan dalam mengajak konsumen melalui promosi yang menarik perhatian. Dalam hal mengajak konsumen, UD. Sarana Multi Niaga memberikan brosur dan kartu nama ketika ikut serta dalam pameran, walaupun konsumen tidak membeli produk.

b. Experience (ajakan), Experience merupakan tahapan dalam brand activation agar pesan dapat tersampaikan sesuai dengan keinginan pelaku usaha dan memberikan pengalaman merek kepada konsumen. UD. Sarana Multi Niaga mengajak konsumen melalui cara memberikan tester beserta edukasi tentang manfaat ikan bandeng beserta cara pengolahannya ketika mengikuti pameran.

c. Amplification (amplifikasi atau penguatan)

Tahapan penguatan merek, biasanya dilibatkan dalam promosi iklan radio, berita atau liputan dan program lainnya. Dalam penguatan merek, UD. Sarana Multi Niaga promosi melalui media sosial dan website, serta e-commerce.

Awareness yang diinginkan oleh UD.

Sarana Multi Niaga kepada konsumen yaitu menjadikan Bandeng Mentari sebagai preferensi merek produk olahan bandeng di kabupaten Gresik, sehingga setiap ingat produk bandeng yaitu Bandeng Mentari asli dari Gresik.

Dana yang dikeluarkan dalam aktivasi merek masuk ke dalam biaya operasional, dimana berkat aktivasi merek UD. Sarana Multi Niaga mengalami kenaikan pendapatan laba mencapai sepuluh persen lebih. Dimana brand menurut pemilik UD. Sarana Multi Niaga mencapai lebih dari 60\%.Sebagai UMKM Unggulan baik di wilayah Gresik maupun di wilayah Jawa Timur.

\section{Packaging yang Unik sebagai Penarik Konsumen}

Adapun yang membedakan Bandeng Mentari dengan produk UMKM lainnya yaitu dengan mengaktivasi packaging, setiap tahunnya packaging Bandeng Mentari di update mengikuti selera pasar. Strategi brand activation dari UD. Sarana Multi Niaga menggunakan beberapa cara diantaranya dengan mengelabuhi konsumen melalui desain bandeng dan mentari, padahal singkatan Bandeng Mentari itu sendiri adalah Bandeng Mentah Tanpa Duri yang merupakan produk awal dari UD. Sarana Multi Niaga sebelum membuat aneka macam olahan bandeng.

Dalam dislay stand pameran pun UD. Sarana Multi Niaga mengaturkan se- kreatif mungkin dengan perlengkapan di dalamnya ada desaindesain, manic-manik, dan perlengkapan display lainnya.

Desain packaging yang menarik dilakukan agar konsumen aware terhadap produk Bandeng Mentari, 
sehingga tidak ragu dari segi kualitas, dan kuantitas yang ditawarkan oleh Bandeng Mentari, serta Bandeng Mentari bisa masuk kluster kelas menengah ke atas.

\section{Mengidentifikasi Target Audience}

Identifikasi target audience merupakan cara untuk mengidentifikasi pasar yang akan dituju oleh perusahaan. Dalam identifikasi target dapat dikorelasikan pada beberapa variabel segmentasi diantaranya geografis, demografis, psikografis, perilaku dan manfaat produk.

Target audience dari UD. Sarana Multi Niaga seluruh kalangan baik menengah ke atas maupun menengah ke bawah sehingga produk Bandeng Mentari dapat dinikmati seluruh kelas sosial di masyarakat. Namun, terdapat klasifikasi produk tersendiri antara kelas menengah ke atas dengan menengah ke bawah, jika menengah ke atas menggunakan produk dengan kuantitas yang besar, sedangkan untuk yang menengah ke bawah menggunakan produk dengan kuantitas lebih kecil, tetapi untuk segi kualitas bandeng tetap kualitas terbaik yang dijualkan baik untuk menengah ke atas ataupun menengah ke bawah. Sasaran untuk menengah ke atas ketika ada event pameran dan modern market, sedangkan untuk menengah ke bawah melalui reseller, dan traditional market.

4. Mencari wawasan konsumen (consumer insight) melalui consumer journey terhadap target audience

Consumer insight sebagai proses dalam mencari tahu secara lebih mendalam dan holistik, tentang latar belakang perbuatan, perilaku konsumen terhadap produk perusahaan. dalam hal ini, UD. Sarana Multi Niaga membidik konsumen yang berlatar belakang keturunan Tionghoa (China) karena semakin banyak memakan bandeng maka semakin banyak pula hoki yang akan didapat. Sehingga dalam kemasan dan packaging pun di desain friendly seluruh konsumen tanpa ada batas-batas tertentu.

Walaupun sebenarnya

Bandeng Mentari berasal dari kota Santri Gresik. Dimana yang biasanya membeli produk Bandeng Mentari di modern market maupun di event pameran sebagian besar merupakan keturunan Tionghoa, bahkan diantara mereka sudah menjadi pelanggan setia produk Bandeng Mentari.

\section{Menentukan saluran Komunikasi (Channel)}

Komunikasi disini, merupakan komunikasi visual terpadu yang dirancang guna mengaktivasi merek melalui serangkaian kegiatan promosi. Saluran komunikasi berikut dalam brand activation meliputi media sosial, website, dan event pameran.

Strategi brand activation sebagaimana yang dijalankan oleh UD. Sarana Multi Niaga yang di dalamnya terdiri dari teori IMC yaitu;

Segmentasi menjadi strategi yang dibangun berdasarkan informasi penting yang menyangkut data-data faktual yang diperoleh dari berbagai sumber mengenai khalayak sasaran. dalam hal ini, UD. Sarana Multi Niaga 
menggunakan segmentasi berdasarkan berdasarkan manfaat, dimana segmentasi ini diterapkan untuk meraih minat beli Bandeng Mentari yang sebagian diminati oleh etnis Tionghoa, dimana dalam kepercayaannya semakin banyak memakan bandeng akan semakin banyak hoki yang didapat.

Target Market merupakan sekelompok orang yang dijadikan sasaran pemasaran produk karena memiliki kebutuhan yang (diasumsikan) sama terhadap suatu produk. Pasar sasaran inilah yang menjadi dasar penyusunan strategi pemasaran, baik dari segi strategi produk, harga, distribusi maupun promosi. Dalam hal ini target dalam pelaksanaan Brand Activation UD. Sarana Multi Niaga yakni semua kalangan baik dari kalangan menengah ke atas, kalangan menengah ke bawah maupun kalangan kelas menengah, namun yang menjadi perbedaan diantara tiga kalangan yaitu dari segi klasifikasi produk, dimana kualitas tetap sama, namun kuantitas dan packaging yang berbeda.

Positioning merupakan langkah memposisikan suatu produk ke dalam kotak-kotak calon konsumen. Hal ini calon konsumen dari diterapkannya strategi brand activation UD. Sarana Multi Niaga yaitu dengan memposisikan pasar, antara modern market, traditional market, rumah makan dan agen,

\section{Kesimpulan}

Berdasarkan hasil temuan data dan konfirmasi teori penjelasan tentang rumusan masalah yang peniliti lakukan, maka dapat diambil beberapa kesimpulan antara lain Brand activation UMKM sangatlah penting, hal ini berguna dalam pengenalan merek dan penanaman merek dalam benak konsumen. Melalui brand activation produk dapat dikenali oleh konsumen secara menyeluruh dan utuh, sehingga dapat mewujudkan brand awareness dari konsumen. Dalam hal ini komunikasi pemasaran terpadu berperan sebagai jembatan antara brand activation dengan konsumen, dimana komunikasi pemsaran terpadu memberikan pedoman apa saja yang perlu diterapkan dalam kegiatan brand activation.

Strategi brand activation yang dijalankan oleh UD. Sarana Multi Niaga ini sebagaimana di dalamnya terdapat teori Komunikasi Pemasaran Terpadu, UD Sarana Multi Niaga dapat memenuhinya sebagai berikut menggunakan Segmentation, Targeting dan Positioning, hal yang sama pula dijalankan melalui tiga bentuk brand activation dari UD. Sarana Multi Niaga yaitu sponshorship, product trial, dan direct selling. Strategi dan bentuk brand Activation inilah yang nanti untuk mewujudkan kesadaran merek (brand awareness) dari konsumen, hal tersebut diwujudkan dengan brand Bandeng Mentari dikenal sebagai kearifan lokal dari kabupaten Gresik 


\section{Daftar Pustaka}

Aaker, D.A. 1991. Managing Brand Equity. New York: The Free Press

A. Shimp, Terence. 2003. Advertising, Promotion, And Other Aspects of Integrated Marketin Communications. South Westren, Thomson: University of South Caroline

Arikunto, Suharsimi. Prosedur Penelitian Suatu Pendekatan Praktek. Jakarta: Rineka Cipta Bagas Pratama, Aditya. 2006. Kamus Lengkap Bahasa Indonesia. Surabaya: Pustaka Media Brannan, Tom. 1998. Pedoman Praktis Untuk Pemasaran Terpadu. Jakarta: Gramedia

Creswell, John W. 2009. Research Design Pendekatan Kualitatif, Kuantitatif, dan Mixed. Yogyakarata: Pustaka Pelajar

Danim, Sudarwan. 2002. Menjadi Peneliti Kualitatif. Bandung: Pustaka Setia

Denscombe, Martyn. 2003. The Good Research Guide, 2nd ed. Philadelphia: Open University Press

Durianto. 2004. Strategi Menaklukan Pasar melalui Riset Ekuitas dan Perilaku Merek. Jakarta: Gramedia Pustaka

E. Maulana, Amalia. 2009. Consumer Insights Via Ethnography. Jakarta: Erlangga

Estaswara, B. Helpris. 2008. Think IMC! Efektifitas Komunikasi untuk Meningkatkan Loyalitas Merek dan Laba Perusahaan. Jakarta: Gramedia

H, Kertajaya. 2005. Markplus on Strategy: 12 Tahun Perjalanan MarkPlus\&Co. Membangun Strategy Perusahaan. Jakarta: Gramedia Pustaka
J. Moleong, Lexy. 2008. Metodologi Penelitian Kualitatif. Bandung: PT. Rosda Karya

Joseph P. Cannon, et.al. 2008. Basic Marketing, A Global-Managerial Aprroach. New York: MC Graw Hill.

Kasali, Rhenald. 2007. Manajemen Periklanan: Konsep dan Aplikasinya di Indonesia. Jakarta: Pustaka Gramedia Utama Grafiti

Keller, Kevin Lane. 2003. Strategic Brand Management: Building, Measuring and Managing

Brand Equity. New Jersey: Prentice Hall

Kliatchko. 2004. J.Understanding Integrated marketing communications. Inkwell Publishing.

Larry Percy. 2008. Strategic Integrated Marketing communication. United Kingdom: ButterworthHeinemann

M. Suryanto. 2005. Strategi Perancangan Iklan Televisi Perusahaan Top Dunia. Yogyakarta: ANDI

M.A, Morissan. Periklanan: Komunikasi Pemasaran Terpadu. Jakarta: Kencana Pranada Media Group

Muktiyo, Widodo. 2006. Membangun Usaha dengan Kekuatan Image. Yogyakarta: Pinus Nasution. 1964. Azas-Azas Kurikulum. Bandung: Terate

Nitisusastro, Mulyadi. 2010. Kewirausahaan \& Manajemen Usaha Kecil. Bandung: Alfabeta

Poerwandari, E. Kristi. 2005. Pendekatan Kualitatif untuk Perilaku Manusia. Jakarta: Mugi Eka Lestari 
Rakhmat, Jalaluddin. 2004. Metode Penelitiaan Komunikasi. Bandung : Remaja Rosdakarya

R. Semiawan, Conny. 2008. MetodePenelitian Kualitatif Jenis Karakteristik dan Keunggulannya. Jakarta: Grasindo

Rangkuti, Freddy. 2009. Strategi Promosi yang Kreatif dan Analisis Kasus Integrated Marketing communication. Jakarta: Gramedia Pustaka Utama

Robiyanto, Febra. 2004. Akuntansi Praktis untuk Usaha Kecil dan Menengah. Semarang,: Studi Nusa

S.M, Siahaan. 1990. Komunikasi, Pemahaman, dan Penerapan. Jakarta: BPK Gunung Mulia Sciffman L.G \& Kanuk, L.L. 1994. Consumer Behaviour. New Jersey. Prentice Hall Siamamora. 2003. Membongkar Kotak Hitam Konsumen. Jakarta: Gramedia Pustaka

Strauss, A. L., and Corbin, J. 1998. Basics of Qualitative Research: Grounded Theory Procedures and Techniques, 2nd edition. Newbury Park, CA: Sage Publications

Sulajsana, Uyung. 2003. Interated Marketing communication: Teks dan Kasus., Yogyakarta: Pustaka Pelajar

Sutisna. 2003. Perilaku Konsumen dan Komunikasi Pemasaran. Bandung: Remaja Rosdakarya Tjiptono, Fandy, Gregorius Chandra \& Andriana, Dadi. 2008. Pemasaran Strategik. Jakarta: Penerbit Andi.

Akifa P. Nayla. 2014. "Komplet Akutansi untuk UKM dan Warabala". Jojakarta

ean-Noel Kapferer. 2012. The New Strategic Brand Management :
Advanced Insights and Strategic Thinking. UK : Kogan Page Limited=

Bolton, Ruth N. 2004. Invited Commentaries on Evolving to a New Doamin Logic for Marketing, Journal of Marketing

Desilya Bunga Arini, Hadi Purnama, Maylanny Christin S.Sos. 2013. Strategi Penerapan Brand activation STAR GLAM MAGAZINE melalui Event Marketing Sunday Morning Bandung. Bandung: Universitas Telkom

Endah, Muwarni. 2004. Dasar-dasar Pemasaran. Jakarta: Univ. Dr.. Moestopo

Finanda, Septi Asri. 2017. Brand activation D'Yon2 n' D' Nyin2. Yogyakarta: Universitas Sarjanawiyata Tamansiswa

Handoko. 2008. New Battlefield, Jurnal Marketing- Marketing Club

International Journal of Commerce and Management Research ISSN: 24551627, Impact Factor: RJIF 5.22 www.managejournal.com Volume 3, Issue 3, March 2017, Page No. 89-91

Kurniawan, Ferry Duwi, Luluk Faizah. 2014. Pemberdayaan Usaha Mikro Kecil dan Menengah (UMKM) dalam penanggulangan kemiskinan. Sidoarjo: Universitas Muhammadiyah Sidoarjo.

Morel, Paul, Peter Preisler and Anders Nystrom (2002).

Brand activation

http://www.metro.as/index.php/con tent/.../13BrandActivation.pdf (Online)

Nurseto, Tejo. 2004. "Strategi Menumbuhkan Wirausaha Kecil 
Menengah yang Tangguh", dalam jurnal Ekonomi \& Pendidikan

Oktavia, Ellora. 2016. Strategi Yang Digunakan Indo Marketing Solution Untuk Menciptakan Brand Awareness Majalah Lahap. Surabaya: Universitas Ciputra

Olof Holm. 2006 "Integrated marketing communication: from tactic to strategggy. Jurnal Corporate Communications

Profil Bisnis UMKM . Lembaga Penembanan Perbankan Indonesia dengan Bank Indonesia tahun 2015

Rahab. 2009. Penerapan Manajemen Merek Pada Ushaa Kecil dan Menengah (UKM). Purwokerto:Universitas Jendral Soedirman Purwokerto.

Rahmadhani, Yuri. 2017. Strategi Branding Portal Online www.tripriau.com Dalam Membangun Brand awareness Sebagai Portal Online Pariwisata Provinsi Riau. Riau: Universitas Riau

Rhohmanditya, Raka. 2016. Perancangan Brand activation Kopi Cap Liong Bulan Sebagai Warisan Kuliner Khas Kota Bogor. Yogyakarta: Institut Seni Indonesia.

Sakur. 2011. Kajian Faktor-faktor yang Mendukung Pengembangan Usaha Mikro Kecil dan Menengah: Studi Kasus di Kota Surakarta Spirit Publik. Surakarta: Universitas Sebelas Maret
Tulasi, Dominikus. 2012. Marketing communication dan Brand awareness. Jakarta: Binus University.

Wahyuningsih. 2009. "Peran UKM dalam Perekonomian Indonesia”, dalam Jurnal Mediargo Yessy Liembawati, Diah Dharmayanti. 2014. Program Manajemen Pemasaran. Surabaya: Universitas Kristen Petra Surabaya 